\title{
Recent Development and Application of Geothermal Heat Pump Systems in Cold-Climate Regions of the US: A Further Investigation
}

\author{
Yao Yu' ${ }^{1}$, Rui Miao', Louis Miller', Huojun Yang1, Gaylord Olson ${ }^{3}$ \\ ${ }^{1}$ Department of Construction Management and Engineering, North Dakota State University, Fargo, USA \\ ${ }^{2}$ Department of Mechanical Engineering, North Dakota State University, Fargo, USA \\ ${ }^{3}$ Seasonal Storage Technologies, Princeton, USA \\ Email: yao.yu@ndsu.edu
}

How to cite this paper: Yu, Y., Miao, R., Miller, L., Yang, H.J. and Olson, G. (2017) Recent Development and Application of Geothermal Heat Pump Systems in ColdClimate Regions of the US: A Further Investigation. Engineering, 9, 625-648. https://doi.org/10.4236/eng.2017.97039

Received: June 26, 2017

Accepted: July 18, 2017

Published: July 21, 2017

Copyright (ङ 2017 by authors and Scientific Research Publishing Inc. This work is licensed under the Creative Commons Attribution International License (CC BY 4.0).

http://creativecommons.org/licenses/by/4.0/

\begin{abstract}
A Geothermal Heat Pump (GHP) system is known to have enormous potential for building energy savings and the reduction of associated greenhouse gas emissions, due to its high Coefficient Of Performance (COP). The use of a GHP system in cold-climate regions is more attractive owing to its higher $\mathrm{COP}$ for heating compared to conventional heating devices, such as furnaces or boilers. Many factors, however, determine the operational performance of an existing GHP system, such as control strategy, part/full-load efficiency, the age of the system, defective parts, and whether or not regular maintenance services are provided. The omitting of any of these factors in design and operation stages could have significant impacts on the normal operation of GHP systems. Therefore, the objectives of this paper are to further investigate and study the existing GHP systems currently used in buildings located in coldclimate regions of the US, in terms of system operational performance, potential energy and energy cost savings, system cost information, the reasons for installing geothermal systems, current operating difficulties, and owner satisfaction to date. After the comprehensive investigation and in-depth analysis of 24 buildings, the results indicate that for these buildings, about $75 \%$ of the building owners are very satisfied with their GHP systems in terms of noise, cost, and indoor comfort. About $71 \%$ of the investigated GHP systems have not had serious operating difficulties, and about $85 \%$ of the respondents (building owners) would suggest this type of system to other people. Compared to the national median of energy use and energy cost of typical buildings of the same type nationwide, the overall performance of the actual GHP systems used in the cold-climate regions is slightly better, i.e. about $7.2 \%$
\end{abstract}


energy savings and $6.1 \%$ energy cost savings on average.

\section{Keywords}

Existing Geothermal Heat Pump, Heating COP, Onsite Survey, Energy and Energy Cost Savings, Cold Climate

\section{Introduction}

According to the Buildings Energy Data Book [1], the US consumes approximately $19 \%$ of the total energy of the world, in which buildings (commercial and residential) account for $41 \%$ of the US energy consumption. However, only $9 \%$ of the US building energy is renewable. Additionally, $45 \%$ of US carbon dioxide $\left(\mathrm{CO}_{2}\right)$ emissions are caused by buildings, compared to $21 \%$ for industry and $34 \%$ for transportation [1]. Due to a large amount of fossil fuel consumption nationwide for buildings, incentives/tax credits are given by local governments or utility companies to encourage the use of renewable energy. A Geothermal Heat Pump (GHP) system is one of the systems that make use of renewable energy, i.e. underground heat/cold, for space heating/cooling in buildings.

It has been well known that a GHP system has enormous potential for building energy savings and the reduction of associated greenhouse gas emissions, due to its high operational efficiency. This type of system takes advantage of the nearly stable underground temperatures to reject/extract heat to/from underground regions. The use of a GHP system in cold-climate regions is more attractive owing to its higher Coefficient Of Performance (COP) for heating compared to conventional heating devices, such as furnaces or boilers, which typically consume natural gas and have a heating efficiency of up to $90 \%-95 \%$. Therefore, plenty of studies have existed in this research area for many years [2]-[12]. For example, most recently, David et al. [2] and Arat and Arslan [3] in 2017 demonstrated the use of large-scale GHP systems for district heating. Liu et al. [4] in 2015 investigated the feasibility and performance of GHP systems used in three cold-climate regions of China, and they found that Beijing, as one of the three investigated regions, is the most suitable city for GHP systems, compared to the other two cities, i.e. Shenyang and Qiqihaer. In 2013, Self et al. [5] compared GHP heating with other heating options, and found out that the use of GHP systems is economically advantageous if the local electricity price is low, which also has the lowest effect on the environment considering the low $\mathrm{CO}_{2}$ emissions. An energy and exergy flow analysis was performed by Lohani and Schmidt [6] in 2010 considering different heating options, including fossil fuels, ground and air source heat pump systems. The result of this comparison revealed that the GHP heating system is better than air source heat pumps and other conventional heat options. The investigation performed by Urchueguía et al. [7] in 2008 on GHP systems revealed that the heating energy savings of the investigated GHP systems can be as high as $60 \%$ compared to conventional 
air-source heat pump systems. Studies on the use of GHP system for greenhouse heating have existed for a number of years [13]-[21]. Moreover, GHP systems can be used for snow melting on pavements and bridge decks [22] [23] [24] [25] [26].

This high performance and the potential for energy and/or energy cost savings give building owners, who are living in cold-climate areas of the US, another option when making the decision on what type of heating system to install in buildings/houses. Additionally, designers/engineers have another alternative to meet local codes/standards and in the meanwhile to bring the green concept into their designs. From the perspectives of governments, designers, and/or engineers, the motivations for the design and use of a GHP system in a real project could be due to its low energy consumption and its reduced effect on the environment. From the building owners' perspectives, however, the capital and operational costs could be the top priorities, especially for private sector projects. Convincing people is not easy, especially convincing them to spend more money now and wait for the payback year after year. In this way, designers/engineers have the responsibilities to educate people (building owners) and show them the potential benefits of using a costly system, e.g. a short payback period. For this reason, the potential benefits of using a GHP system are quantified in a form of energy and energy cost savings in comparison to so-called conventional systems, even though most of the building owners have no idea what the conventional systems referred by designers/engineers actually are. The gap in the understanding of building mechanical system design between designers and building owners may leave hidden troubles for the future use and operation of GHP systems. For example, William [27] conducted a comparison of carbon emission between residential heating and cooling options and found that for a residential building located in Daytona Beach, Florida, and equipped with a high-efficiency GHP system, no significant energy savings were observed compared to a conventional air-conditioning system. This was apparently against the original expectation of the building owner and the designer team.

Actually, there is an essential difference for a GHP system between simulation/expectation mode and real operation mode. A real existing system, not including a system built up in a lab for research purposes, may operate very differently from a simulated system through computer modeling, which is assumed to be controlled ideally and that no regular maintenance is needed. The operation of an existing GHP system could be influenced by many factors that usually cannot be fully included in computer simulations, such as

- the actual control strategies implemented by building owners or operators and if they are appropriately designed for the building usage,

- defective parts in the system,

- the age of the system which may be too old to maintain the high efficiency,

- implementation of regular maintenance services to maintain normal operation of the system.

The omitting of any of these factors in design and operation stages could have 
significant impacts on the normal operation of GHP systems as well as the achievement of expected energy and energy cost savings. Therefore, the study described in this paper aims to further investigate existing GHP systems installed in buildings located in cold climates of the US, e.g. in the state of North Dakota, representing the Climate Zone 6 and 7 as described in the American Society of Heating, Refrigerating and Air-Conditioning Engineers (ASHRAE) Standard [28]. The significance of this study focuses on the following aspects,

- finding out whether these systems are operating as anticipated and designed

- comparing these systems with national median buildings (the Environmental Protection Agency (EPA)'s Energy Star Target Finder [29] result for a national median property), in terms of building energy use and energy cost

- identifying common operating difficulties of these existing GHP systems

- identifying the possible barriers to the wide application of GHP systems in the northern regions of the US

- demonstrating owner's satisfaction with their GHP systems

- investigating the motivations of building owners in installing GHP system in the first place

- investigating the capital cost information of installing GHP systems in cold-climate regions of the US (in terms of $\$ / \mathrm{m}^{2}$ )

- providing a reference to building designers/contractors for GHP applications and establishing the acceptance of potential end users in cold-climate regions The methodologies used in this study mainly include on-site surveys and investigations through questionnaires, data and information request and collection, as well as data classification and analysis.

Although similar studies [30]-[39] were done, where some commercial buildings equipped with GHP systems were investigated at different times, in terms of system performance, operating difficulties, owner satisfaction, etc., our study can be considered as an extension or a further investigation based on the existing studies and will focus on the recent development and application of GHP systems in cold-climate regions of the US. This is also regarded as the purpose/goal of this study.

\section{On-Site Surveys and Investigations}

As the first step of this study, on-site surveys and investigations took place, which included three tasks, i.e. selecting the target buildings, obtaining the permissions for on-site investigations, and preparing the survey documents.

\subsection{Selecting the Target Buildings}

The target buildings in this study are the buildings located in cold-climate regions of the US (North Dakota) and equipped with GHP systems (closed-loop, open-loop, and/or direct-exchange if available).

Manz [40] conducted an investigation in 2011 about the locations of geothermal installations in the cold-climate regions (Figure 1). In this figure, different colors and sizes of spots represent the different numbers of geothermal 


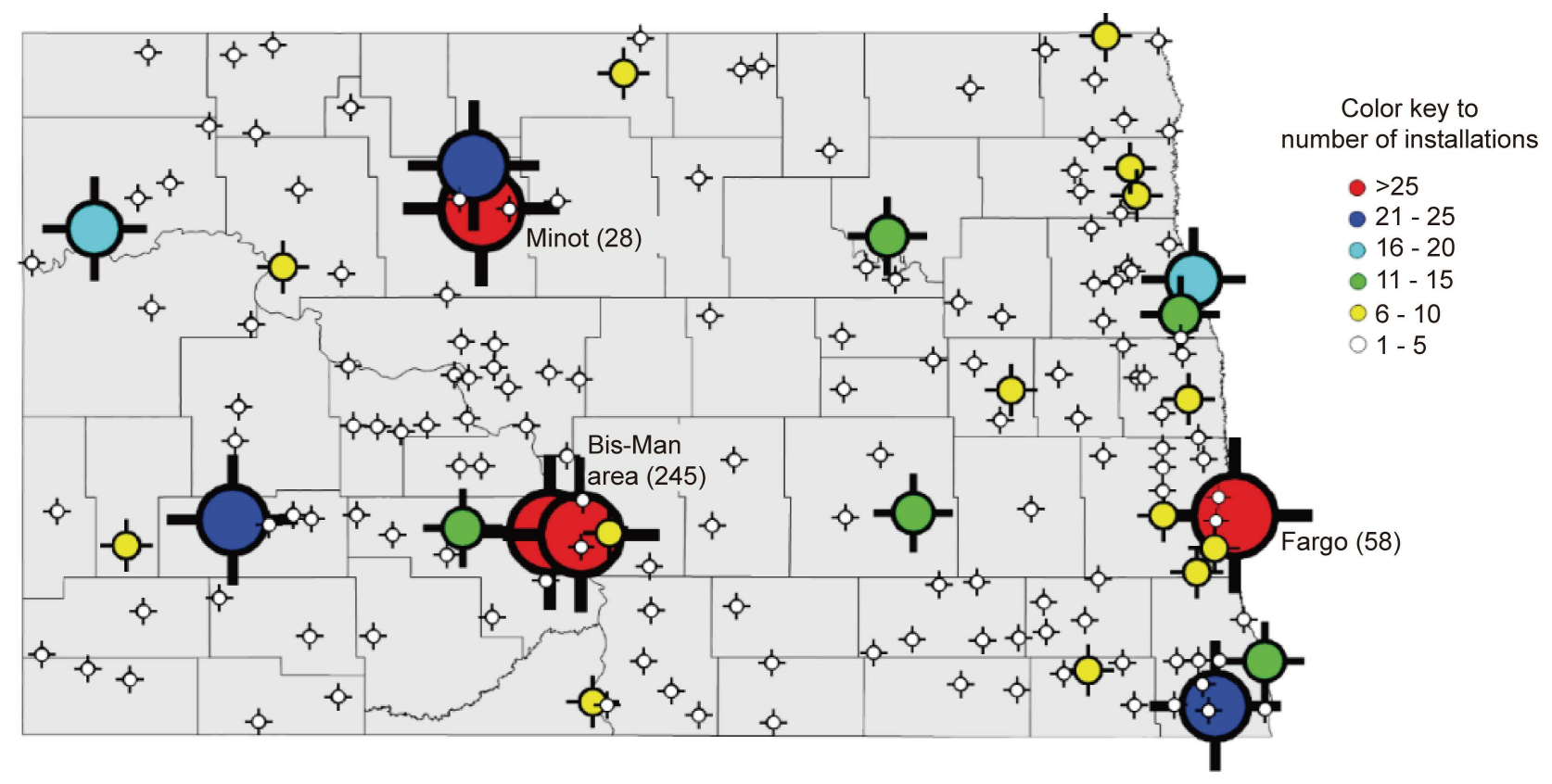

Figure 1. Locations of geothermal installations in North Dakota [40].

installations. This figure was regarded as a reference in this study when selecting target buildings.

\subsection{Obtaining the Permissions}

Requests were sent to the building owners through email, fax, or phone call, in order to ask whether they are willing to participate in the survey and to obtain permission for on-site investigations. Responses were received from 37 building owners with the total 84 requests that were sent out. These owners showed the willingness to help our research and provide necessary building information/documents. Eventually, the final list of the target buildings was generated (with 24 of these 37 buildings), considering several factors, such as the building locations and types, the ages of GHP systems, and the richness and availability of the received information and documents of each building. These 24 buildings include 9 college buildings, 6 school buildings, 2 churches, 3 commercial buildings, 2 public buildings, and 2 residential buildings, three of which are LEED (Leadership in Energy and Environmental Design) certified buildings.

Figure 2 indicates the target buildings by different building types. The location of each target building in the final list was selected carefully in order to cover most of the typical areas in the cold-climate regions, as shown in Figure 3.

Another critical factor that needs to be considered in the study is the years the structures and the GHP systems were built and installed. After certain years, some of the heat pump units could be too old to be used due to high maintenance cost and/or low operation efficiency. These target buildings were categorized into two groups depending on the years for which their heat pump systems have been used (Table 1).

As shown in Table 1, no GHPs have the system age of more than 25 years, 


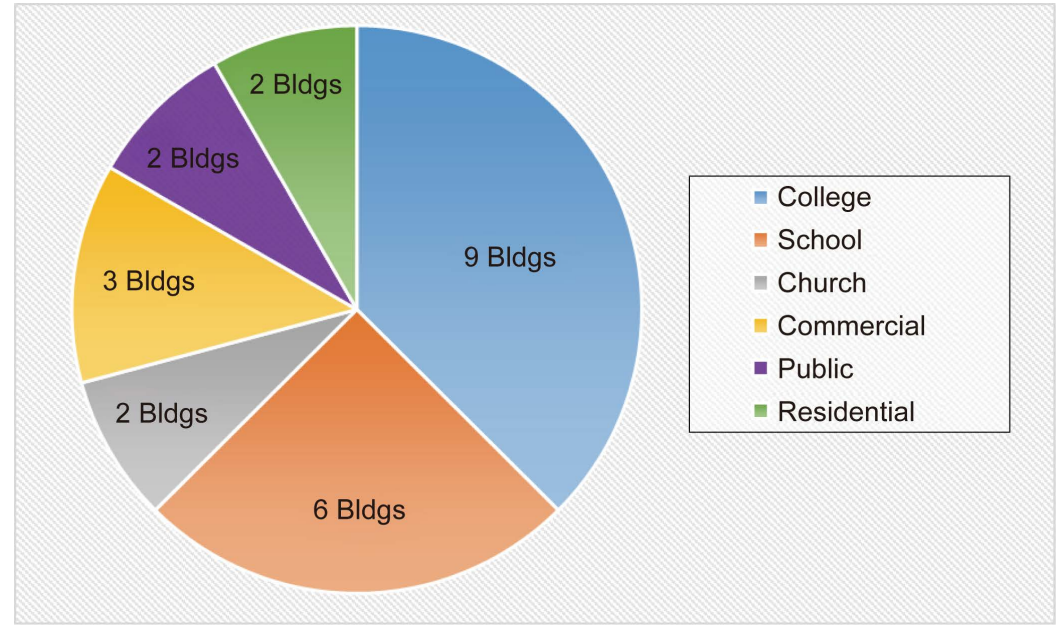

Figure 2. Target building allocation by building type.

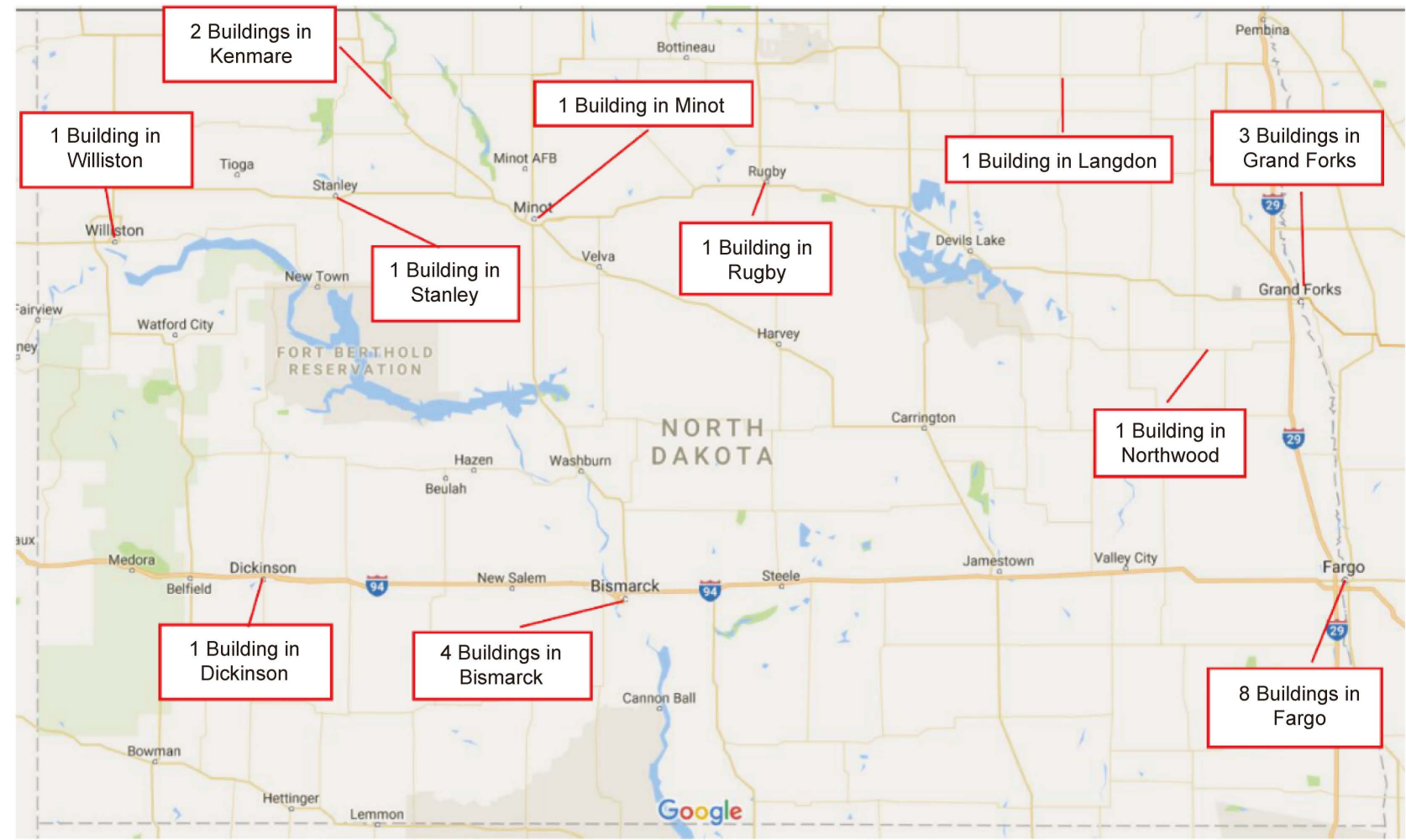

Figure 3. Target buildings on a Google map.

Table 1. Two groups for building selection based on the age of heat pump system.

\begin{tabular}{ccc}
\hline Groups & Heat Pump System Age [years] & Number of Buildings \\
\hline Group One & $<10$ & 13 \\
Group Two & $\geq 10$ and $\leq 25$ & 11 \\
\hline
\end{tabular}

considering the fact that the effective life of an indoor heat pump unit is typically 20 - 25 years, and thus older heat pump units had already been replaced with new ones in buildings. 


\subsection{Preparing the Survey Documents}

The survey documents were prepared for the on-site investigations, including the following:

- The on-site survey questionnaires for building owners, end users and/or maintenance staffs. Questions in the questionnaires include the reasons for installing a GHP system, the capital costs of the building and Heating, Ventilation and Air Conditioning (HVAC) systems, if there are operating difficulties, and the satisfaction of the owners and/or end users, as well as the basic building and system information including building type, building floor area, the ages of building and HVAC system, the numbers of heat pump units and boreholes/wells, and service providers.

- A list indicating the detailed building information that needs to be requested from the owners and/or the design companies, including design plans/ drawings (architectural, mechanical, electrical, etc.) and/or specifications, the annual utility bills, the maintenance activity log and cost, and the design documents, such as the Owner's Project Requirements (OPR), the Basis Of Design (BOD), and the installation and operations manuals.

The on-site visits took place right after the obtaining of permissions and the completion of preparing survey documents. During the building visit, the survey questionnaire was completed, and the detailed information and documents were requested and collected. The result of the on-site visit and investigation is organized and demonstrated below.

\section{Results and Discussions}

Specifically, this paper includes the case studies of 24 target buildings that are located in the cold-climate regions of the US (Climate Zone 6 and 7) and equipped with GHP systems. The results of these 24 case studies are summarized below, including Building Background, Building Mechanical System Parameters, Building Energy Consumption, Building Cost Demonstration, and Owner Satisfaction.

\subsection{Building Background}

The background information of these 24 target buildings is summarized in $\mathrm{Ta}$ ble 2 (with the numbering of buildings from 1 to 24), including building area, building construction year, building type, and whether or not the building is LEED certified. As shown in this table, the target buildings have the building areas between 697 and $25920 \mathrm{~m}^{2}$, with the building construction years from 1917 to 2013.

Within these 24 buildings, three of them are LEED certified buildings, including one LEED Platinum building, one LEED Gold building, and one LEED Silver building. LEED is one of the most popular green building certification programs used worldwide. LEED typically has four levels of certification, i.e. Certified, Silver, Gold, and Platinum. A higher certification level represents a higher achievement in green buildings in terms of sustainability. 
Table 2. Building background summary.

\begin{tabular}{|c|c|c|c|c|}
\hline Building Number & Building Total Area $\left[\mathrm{m}^{2}\right]$ & Building Construction Year & Building Type & LEED Building \\
\hline 1 & 12542 & 2009 & College & No \\
\hline 2 & 9866 & $\begin{array}{c}2008 \\
2013 \text { for the } 4 \text { th floor }\end{array}$ & College & No \\
\hline 3 & 2973 & 2010-2012 & College & No \\
\hline 4 & 1782 & 2006 & College & No \\
\hline 5 & 2604 & 2003 & College/Dormitory & No \\
\hline 6 & 970 & 2006 & College/Office & No \\
\hline 7 & 697 & 2004 & College/Office & No \\
\hline 8 & 3530 & 2012 & College & LEED - Platinum \\
\hline 9 & 5652 & 2011 & College/Dormitory & No \\
\hline 10 & 19045 & 1994 & Middle School & No \\
\hline 11 & 8330 & $\begin{array}{c}2007 \\
2012 \text { for New Addition }\end{array}$ & Elementary School & No \\
\hline 12 & 25920 & 2011 & High School & No \\
\hline 13 & 8386 & $\begin{array}{c}1999 \\
2009 \text { for New Addition }\end{array}$ & Elementary School & No \\
\hline 14 & 9569 & 2008 & Public School & No \\
\hline 15 & 9197 & 1956 & High School & No \\
\hline 16 & 2230 & 2006 & Church & No \\
\hline 17 & 4645 & $1917-1932$ & Church & No \\
\hline 18 & 4975 & 2011 & Commercial/Airport Terminal & LEED - Silver \\
\hline 19 & 1249 & 2012 & Commercial/Office & LEED - Gold \\
\hline 20 & 5342 & 2008 & Commercial/Office & No \\
\hline 21 & 1118 & 2009 & Public/Fire Station & No \\
\hline 22 & Unknown & 1992 & Public/Office & No \\
\hline 23 & Unknown & 2002 & Residential & No \\
\hline 24 & Unknown & 2003 & Residential & No \\
\hline
\end{tabular}

\subsection{Building Mechanical System Parameters}

The mechanical system parameters of these 24 target buildings are summarized in Table 3, including HVAC/GHP installation year, installation type (new or retrofit), GHP system type, the number of boreholes, borehole depth, borehole separation distance, borehole length, borehole length per $\mathrm{kW}$ (total cooling capacity), and GHP water flow rate per kW (total cooling capacity). Since each borehole of all the vertical and horizontal GHP systems investigated is configured with a pair of pipes (single U-tube) that are joined by a U-bend at the bottom of the hole, the underground pipe length and the underground pipe length per $\mathrm{kW}$ are a factor of 2 larger than the corresponding borehole length and borehole length per $\mathrm{kW}$, respectively, for each system. Therefore, these two parameters, 
Table 3. Building mechanical system summary.

\begin{tabular}{|c|c|c|c|c|c|c|c|c|c|}
\hline BldgNO. & $\begin{array}{l}\text { HVAC/GHP } \\
\text { Instl. Yr }\end{array}$ & Instl. Type & $\begin{array}{l}\text { GHP } \\
\text { type* }\end{array}$ & $\begin{array}{c}\text { NO. of } \\
\text { Boreholes }\end{array}$ & $\begin{array}{c}\text { Borehole } \\
\text { Depth } \\
{[\mathrm{m}]}\end{array}$ & $\begin{array}{l}\text { Borehole } \\
\text { Separation } \\
\text { Dist. [m] }\end{array}$ & $\begin{array}{l}\text { Borehole } \\
\text { Length } \\
{[\mathrm{m}]}\end{array}$ & $\begin{array}{c}\text { Borehole } \\
\text { Length per } \\
\mathrm{kW}[\mathrm{m} / \mathrm{kW}]\end{array}$ & $\begin{array}{c}\text { GHP water } \\
\text { flow rate per } \\
\mathrm{kW}[\mathrm{L} / \mathrm{min} / \mathrm{kW}]\end{array}$ \\
\hline 1 & 2009 & $\begin{array}{l}\text { New for the } \\
\text { addition }\end{array}$ & V & 120 & 62 & 4.6 & 7425 & 23.4 & 4.8 \\
\hline 2 & 2008 & New & V & 504 & 61 & 4.6 or less & 30724 & Unknown & Unknown \\
\hline 3 & $2010-2012$ & New & V & 130 & 61 & 4.6 & 11887 & 31.3 & 5.8 \\
\hline 4 & 2006 & New & V & 36 & 61 & 4.6 & 2195 & 13.3 & 3.0 \\
\hline 5 & 2003 & New & V & 70 & 61 & 4.6 & 4267 & 14.8 & 3.2 \\
\hline 6 & 2006 & New & V & 30 & 61 & 4.6 & 1829 & 17.3 & 3.8 \\
\hline 7 & 2010 for Upgrade & $\begin{array}{l}\text { Retrofit/ } \\
\text { Upgrade }\end{array}$ & V & 26 & 61 & $3-4.6$ & 1585 & 19.4 & 3.9 \\
\hline 8 & 2012 & New & V & 142 & 64 & 4.6 & 9089 & 18.7 & 3.9 \\
\hline 9 & 2011 & New & $\mathrm{V}$ & 120 & 91 & 6.1 & 10973 & 20.4 & 3.3 \\
\hline 10 & $\begin{array}{l}\text { Ground loop and } \\
\text { HPs: } 1994 \\
73 \text { replacement } \\
\text { HPs: } 2013\end{array}$ & New & V & 688 & 46 & 3.0 & 31455 & Unknown & Unknown \\
\hline 11 & $\begin{array}{l}2007 \text { with } 50 \text { HPs } \\
2012 \text { for New } \\
\text { Addition with } \\
9 \text { new HPs }\end{array}$ & New & V & 288 & $46-61$ & $2.4-3.7$ & 13167 & 17.2 & 4.3 \\
\hline 12 & 2011 & New & V & 928 & 61 & Unknown & 56571 & 20.0 & 3.1 \\
\hline 13 & $\begin{array}{c}1999 \text { with } 54 \text { HPs } \\
2009 \text { for New } \\
\text { Addition with } \\
3 \text { new HPs }\end{array}$ & New & V & 320 & 46 & $2.4-3.7$ & 14630 & 18.1 & 4.1 \\
\hline 14 & 2008 & New & $\mathrm{V}$ & 384 & 61 & 4.6 & 23409 & 20.9 & 3.9 \\
\hline 15 & 2012 & Retrofit & V & 72 & 76 & 6.1 & 5486 & 13.3 & 2.3 \\
\hline 16 & 2006 & New & V & 48 & 61 & 4.6 & 2926 & 16.6 & 3.3 \\
\hline 17 & 2005 & Retrofit & V & 100 & 46 & Unknown & 4572 & Unknown & Unknown \\
\hline 18 & 2011 & New & $\mathrm{HB}$ & 16 & $\begin{array}{c}7.6 \text { and } \\
12.2\end{array}$ & 6.1 & $\begin{array}{c}\text { 152/ea. } \\
\text { Total: } 2432\end{array}$ & 7.2 & 2.5 \\
\hline 19 & 2012 & New & V & 26 & 61 & 4.6 & 1585 & 12.2 & 2.6 \\
\hline 20 & 2008 & New & V & 80 & 61 & 4.6 & 4877 & 20.2 & 4.5 \\
\hline 21 & 2009 & New & V & 18 & 61 & 4.6 & 1097 & 19.2 & 4.0 \\
\hline 22 & 1992 & New & & & & & & & \\
\hline 23 & 2002 & New & \multicolumn{7}{|c|}{ Unknown } \\
\hline 24 & 2003 & New & & & & & & & \\
\hline
\end{tabular}

${ }^{*} \mathrm{~V}$ represents Vertical closed-loop system; HB represents Horizontally Bored closed-loop system. 
i.e. underground pipe length and underground pipe length per $\mathrm{kW}$, can be easily determined and are not shown in Table 3 and Table 4. Also in Table 3, some of the system parameters are marked as "Unknown", due to the limited information obtained from the building owners. Table 4 summarizes the average values of these mechanical parameters along with the heat pump efficiency range.

As shown in Table 3, the average age of these 24 investigated GHP systems is about 11 years old, which is about in the middle of the lifespan of a typical heat pump system. A GHP system with this age is appropriate for this study, since it is neither too old nor young and can effectively reflect the operational performance of a typical GHP system.

Most of the GHP systems were the original systems for the investigated buildings, and the owners decided to install them in the first place. The owners of three buildings, i.e. Building 7, 15 and 17, decided to use GHP systems after the failures of their original non-GHP systems. The reason for choosing and installing GHP systems in the first place for each target building is summarized in Table 5. According to this table, the common reasons are listed below,

- Lower cooling and heating bills;

- Energy efficiency;

- Environmental concerns.

It is not surprising that "lower cooling and heating bills" ranks the first, but the good thing is that some of the building owners expressed more concerns about energy and environment. These owners, however, are limited to college or school buildings (non-profit organizations). For commercial buildings, reducing the utility bills is still the top concern, which may help them to reduce overhead cost and thus increase profit.

Unsurprisingly, most of the investigated GHP systems are vertical closed-loop systems, as shown in Table 3, which are obviously the most common systems used in these regions and are the most mature and reliable GHP systems for designers/engineers. A horizontally bored closed-loop system was installed in one of the commercial buildings, i.e. Building 18. This facility, however, was originally designed to use a vertical closed-loop GHP system until the constructor found an unusually high water table during construction.

Table 4. Average value comparison of mechanical system parameters.

\begin{tabular}{|c|c|c|c|}
\hline & Average & Range & Typical Value \\
\hline Number of Boreholes for Vertical GHP & $207^{\star *}$ & $18-928^{\star *}$ & Varies \\
\hline \multirow{2}{*}{ Borehole Depth [m] } & Vertical: 63 & Vertical: 46 - 91 & Vertical: $15-137$ \\
\hline & Horizontally bored: 10 & Horizontally bored: 7.6 - 12.2 & Horizontally bored: 9.1 - 15.2 \\
\hline Borehole Separation Distance $[\mathrm{m}]$ & 4.9 & $2.4-6.1$ & $4.6-6.1$ \\
\hline GHP water flow rate per $\mathrm{kW}[\mathrm{L} / \mathrm{min} / \mathrm{kW}]$ & 3.7 & $2.3-5.8$ & $2.7-3.2$ \\
\hline \multirow{2}{*}{ Heat Pump Efficiency Range } & Cooling: 4.16 - 5.07 COP & Cooling: $2.46-8.79 \mathrm{COP}$ & Mini. Cooling: 3.93 COP \\
\hline & Heating: $3.1-3.9$ COP & Heating: $2.5-6.4 \mathrm{COP}$ & Mini. Heating: $3.1 \mathrm{COP}^{\star \star \star}$ \\
\hline
\end{tabular}

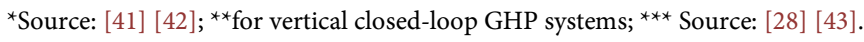


Table 5. Reasons for installing GHP systems.

\begin{tabular}{|c|c|c|}
\hline Bldg. NO. & Building Type & Reasons for installing GHP systems \\
\hline 1 & College & $\begin{array}{l}\text { I wasn't here at the time, but I believe it was to lower heating/cooling bills and } \\
\text { for environmental concerns. }\end{array}$ \\
\hline 2 & College & $\begin{array}{l}\text { Not Provided (the building was built about } 10 \text { years ago, and the persons involved } \\
\text { in this building project were gone. }\end{array}$ \\
\hline 3 & College & Energy efficiency \\
\hline 4 & College & Energy efficiency \\
\hline 5 & College/Dormitory & Energy efficiency \\
\hline 6 & College/Office & Not Provided \\
\hline 7 & College/Office & $\begin{array}{l}\text { Reduce cooling and heating bills } \\
\text { More environmentally friendly } \\
\text { We were experiencing significant problems with the original system }\end{array}$ \\
\hline 8 & College & Green product environment concerns \\
\hline 9 & College/Dormitory & $\begin{array}{l}\text { Not Provided (The building and its geothermal system were completed prior } \\
\text { to my arrival at the college.) }\end{array}$ \\
\hline 10 & Middle School & Green product environment concerns \\
\hline 11 & Elementary School & Green product environment concerns \\
\hline 12 & High School & Green product environment concerns \\
\hline 13 & Elementary School & Green product environment concerns \\
\hline 14 & Public School & Not Provided \\
\hline 15 & High School & $\begin{array}{l}\text { Outdated HVAC system (original system). Added cooling to create a better } \\
\text { learning environment. }\end{array}$ \\
\hline 16 & Church & Design of new building to be more efficient \\
\hline 17 & Church & Lower heating and cooling bills \\
\hline 18 & Commercial/Airport Terminal & Lower heating and cooling bills \\
\hline 19 & Commercial/Office & $\begin{array}{l}\text { To aid in obtaining LEED status, and to be seen a good steward of resources } \\
\text { in the eyes of our customers, suppliers, and the general public. }\end{array}$ \\
\hline 20 & Commercial/Office & Efficient heating system with low operating cost \\
\hline 21 & Public/Fire Station & Not Provided \\
\hline 22 & Public/Office & Lower heating and cooling bills (long-term cost savings) \\
\hline 23 & Residential & Lower heating and cooling bills (long-term cost savings) \\
\hline 24 & Residential & Lower heating and cooling bills (long-term cost savings) \\
\hline
\end{tabular}

As shown in Table 4, the number of vertical boreholes of these investigated GHP systems varies from 18 to 928 . The horizontally bored pipe system has 16 horizontal boreholes that are buried underground with a very long borehole length (152 meters for each) in order to offset the disadvantage of shallower borehole locations underground compared to vertical closed-loop systems. The average borehole depth of the vertical GHP systems is about 63 meters, which is common in these regions, considering the local geologic formation and a relatively high water table. The underground heat exchangers of the horizontally 
bored system are buried underground with the depth of 7.6 and 12.2 meters (two layers) below the ground surface.

The borehole separation distance shown in Table 3 and Table 4 represents the horizontal distance between two close vertical boreholes. Boreholes that are placed too close to each other may result in the accumulation of building heat or cold in the underground region without effective dissipation. The minimum suggested borehole separation distance is 4.6 meters [41]. As shown in Table 3, the GHP systems of several investigated buildings have the borehole separation distances less than the minimum requirement, including Building 2, 7, 10, 11, and 13. Among these buildings, only Building 2 (a college building) was reported by the owner that the ground temperature has been significantly increased by as much as $21^{\circ} \mathrm{C}$, since the GHP system was originally installed with the ground temperature of around $10^{\circ} \mathrm{C}$. The reason for the increased underground temperature is due to the fact that this facility is south-facing and is covered with a large number of windows, so the cooling degree days are significantly more than the heating degree days (cooling-dominated building). In other words, this building may need cooling instead of heating even during a winter season, due to a large amount of solar gains and/or internal gains because of people (students), lighting, and equipment. Additionally, the separation distance between boreholes is less than the minimum suggested value for a vertical geothermal system (4.6 meters), and the ground heat exchanger length is probably insufficient. As a result, more heat is conveyed and stored into the well field than being removed, which has the effect of increasing the ground temperature over time. This puts extreme stress on the heat pumps and results in inefficient operation, or even may cause the failures or complete shut-down of the GHP system. Figure 4

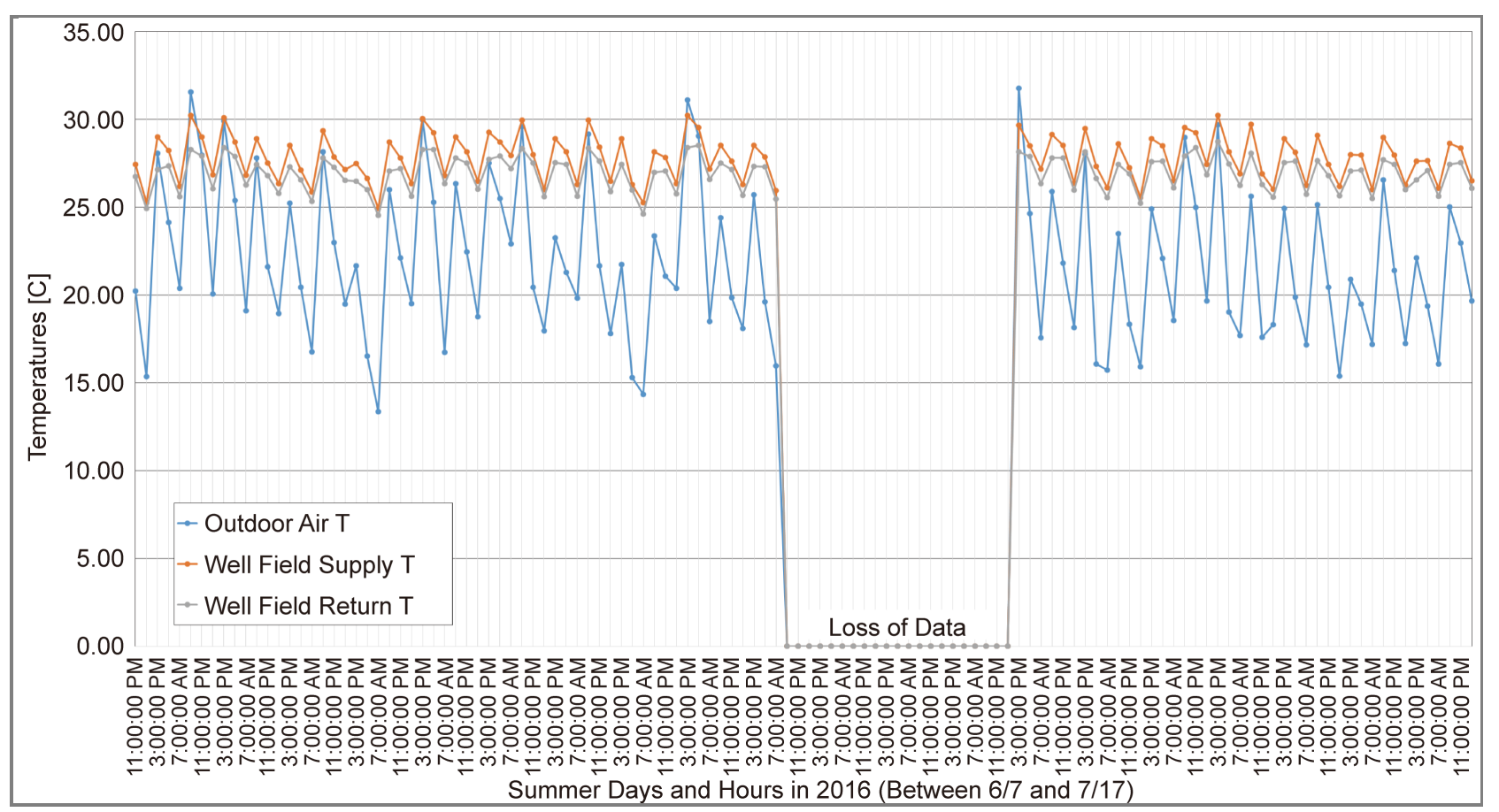

Figure 4. Ground water temperature profiles during the summer of 2016. 
shows the supply and return water temperatures of the ground loop against the outdoor dry-bulb air temperatures during the summer of 2016 (6/7 - 7/17) with the full operation of the circulation pump. This indicates a very small loop temperature differential, and it follows a low efficiency and cooling capacity.

A solution to this problem in this building is to use a hybrid GHP system by adding an additional sink element of thermal energy to deal with the unbalanced heat rejection. Therefore, a dry cooler was installed with the GHP system of this building in 2016. This installation allows water being returned to the ground to first be cooled by this dry cooler during the colder months of the year, and thus the cooler water is circulated into the warmer ground to effectively cool it down over time. With this system in place, it is expected by the building owner to take about three years of continual running of the system in the winter months to cool the ground temperature to an appropriate level.

So far, for the other buildings, i.e. Building 7, 10, 11, and 13, there have been no complaints reported by the building owners regarding the operations of their GHP systems, such as warm ground, low heat pump efficiency, or high utility cost. The potential threats, however, still exist for these buildings and/or other buildings with a relatively insufficient ground heat exchanger length, such as Building 18 or 19 , which should get the attention of the building owners/operators.

As shown in Table 4, the average design value of the borehole length per $\mathrm{kW}$ (total cooling capacity) for these investigated GHP systems is $18 \mathrm{~m} / \mathrm{kW}$, which is in the middle range of the suggested values shown in this table.

The average water flow rate per $\mathrm{kW}$ (total cooling capacity) of all the investigated systems shown in Table 4 is $3.7 \mathrm{~L} / \mathrm{min} / \mathrm{kW}$ (a range between 2.3 and 5.8), which is slightly more than the upper level of the typical values $(2.7-3.2$ $\mathrm{L} / \mathrm{min} / \mathrm{kW}$ ). The higher $\mathrm{L} / \mathrm{min} / \mathrm{kW}$ might indicate the oversizing of the water flow rate in the underground loops in several buildings, e.g. the college building of Building 3, which has the design $\mathrm{L} / \mathrm{min} / \mathrm{kW}$ of 5.8 . The oversizing may result in higher pump power and increased operational costs.

The heat pump efficiency range for each GHP system investigated is shown in Table 4. The average cooling efficiency is between 4.16 and 5.07 COP, and the heating efficiency is between 3.1 and 3.9 COP. Considering the average age (11 years) of these 24 investigated GHP systems, these average efficiency values are compared with the minimum efficiencies of the relatively old standard [28] [43], i.e. $3.93 \mathrm{COP}$ for cooling and $3.1 \mathrm{COP}$ for heating. It appears that these average efficiencies of the actual GHP systems all meet the minimum code/standard requirements.

\subsection{Building Energy Consumption}

In this study, the building energy consumption of these 24 buildings was analyzed and demonstrated in a comparative way, where the online tool of EPA's Target Finder Calculator was used. The Energy Star Target Finder is EPA's online calculator that helps architects, engineers, and property owners and manag- 
ers assess the energy performance and track energy costs and carbon emissions of commercial building designs and existing buildings [29]. The Energy Star Target Finder result represents the national median of energy performance of buildings similar to the target ones in the US. The use of this online tool allows to approximately identify the energy savings between the current GHP system and a system for a similar building nationwide. Table 6 shows the energy use and energy savings for each target building, where Site EUI (Energy Use Intensity) represents the amount of heat and electricity consumed by a building as reflected in the utility bills. The energy consumption information for several buildings is not shown in this table (marked as "Not Available"), due to the limited information obtained from the building owners.

Table 6. Energy use and savings.

\begin{tabular}{|c|c|c|c|}
\hline \multirow[b]{2}{*}{ Bldg. NO. } & \multicolumn{2}{|c|}{ Site EUI $\left[\mathrm{kWh} / \mathrm{m}^{2} / \mathrm{yr}\right]$} & \multirow[b]{2}{*}{$\begin{array}{l}\text { Energy Savings Compared } \\
\text { to Similar Buildings (EPA) }\end{array}$} \\
\hline & $\begin{array}{l}\text { Actual GHP } \\
\text { System }\end{array}$ & $\begin{array}{l}\text { EPA Similar } \\
\text { Building }\end{array}$ & \\
\hline 1 & 233.3 & 371.6 & $37 \%$ \\
\hline 2 & 255.7 & 263.9 & $3 \%$ \\
\hline 3 & 152.5 & 268.7 & $43 \%$ \\
\hline $\begin{array}{l}4 \\
5\end{array}$ & \multicolumn{3}{|c|}{ Not Available } \\
\hline 6 & 154.7 & 162.3 & $5 \%$ \\
\hline 7 & 246.6 & 181.8 & $-36 \%$ \\
\hline 8 & 165.1 & 271.2 & $39 \%$ \\
\hline 9 & \multicolumn{3}{|c|}{ Not Available } \\
\hline 10 & 179.9 & 133.5 & $-34 \%$ \\
\hline 11 & 129.4 & 142.1 & $10 \%$ \\
\hline 12 & 176.8 & 138.9 & $-28 \%$ \\
\hline 13 & 157.9 & 164.2 & $4 \%$ \\
\hline 14 & \multicolumn{3}{|c|}{ Not Available } \\
\hline 15 & 135.8 & 145.2 & $7 \%$ \\
\hline 16 & 96.9 & 97.9 & $1 \%$ \\
\hline 17 & 164.8 & 162.3 & $-2 \%$ \\
\hline 18 & 274.7 & 300.5 & $9 \%$ \\
\hline 19 & 137.0 & 200.5 & $32 \%$ \\
\hline 20 & 145.2 & 217.2 & $34 \%$ \\
\hline 21 & 220.0 & 215.9 & $-2 \%$ \\
\hline 22 & & & \\
\hline 23 & \multirow{2}{*}{\multicolumn{3}{|c|}{ Not Available }} \\
\hline 24 & & & \\
\hline
\end{tabular}


The corresponding energy cost savings are shown in Table 7, and Table 8 summarizes the average values of the site EUIs, energy cost densities, and energy and energy cost savings mentioned before. As shown in Table 8, the average energy cost density of these investigated buildings is about $\$ 13.13 / \mathrm{m}^{2} / \mathrm{yr}$, which is lower than the average energy cost density of the EPA similar buildings $\left(\$ 14.96 / \mathrm{m}^{2} / \mathrm{yr}\right)$. Compared to the national median (EPA results), the overall performance of the actual GHP systems used in these regions is slightly better, i.e. about $7.2 \%$ energy savings and $6.1 \%$ energy cost savings on average. As shown in Table 7, reduced savings or even no cost savings are found when comparing some of the investigated buildings with EPA similar buildings (the national median), such as Building 7, 10,12,17, and 21. For these buildings, the advantage of using GHP systems is not fully apparent, which could be caused by

Table 7. Energy cost savings.

\begin{tabular}{|c|c|c|c|}
\hline \multirow{2}{*}{ Bldg. NO. } & \multicolumn{2}{|c|}{ Energy Cost Density $\left[\$ / \mathrm{m}^{2} / \mathrm{yr}\right]$} & \multirow{2}{*}{$\begin{array}{l}\text { Energy Cost Savings Compared } \\
\text { to Similar Buildings (EPA) }\end{array}$} \\
\hline & Actual GHP System & EPA Similar Building & \\
\hline 1 & $\$ 13.24$ & $\$ 21.10$ & $37 \%$ \\
\hline 2 & $\$ 20.34$ & $\$ 20.88$ & $3 \%$ \\
\hline 3 & $\$ 12.16$ & $\$ 21.42$ & $43 \%$ \\
\hline $\begin{array}{l}4 \\
5\end{array}$ & \multicolumn{3}{|c|}{ Not Available } \\
\hline 6 & $\$ 12.92$ & $\$ 13.67$ & $5 \%$ \\
\hline 7 & $\$ 16.79$ & $\$ 12.49$ & $-35 \%$ \\
\hline 8 & $\$ 15.18$ & $\$ 19.27$ & $21 \%$ \\
\hline 9 & \multicolumn{3}{|c|}{ Not Available } \\
\hline 10 & $\$ 11.09$ & $\$ 8.29$ & $-34 \%$ \\
\hline 11 & $\$ 9.47$ & $\$ 10.66$ & $11 \%$ \\
\hline 12 & $\$ 13.35$ & $\$ 10.44$ & $-28 \%$ \\
\hline 13 & $\$ 11.30$ & $\$ 11.84$ & $4 \%$ \\
\hline 14 & \multicolumn{3}{|c|}{ Not Available } \\
\hline 15 & $\$ 8.72$ & $\$ 9.36$ & $7 \%$ \\
\hline 16 & $\$ 8.50$ & $\$ 8.61$ & $1 \%$ \\
\hline 17 & $\$ 7.00$ & $\$ 6.89$ & $-2 \%$ \\
\hline 18 & $\$ 22.17$ & $\$ 26.05$ & $15 \%$ \\
\hline 19 & $\$ 14.32$ & $\$ 20.99$ & $32 \%$ \\
\hline 20 & $\$ 12.92$ & $\$ 19.48$ & $34 \%$ \\
\hline 21 & $\$ 14.21$ & $\$ 12.81$ & $-11 \%$ \\
\hline 22 & & & \\
\hline 23 & \multirow{2}{*}{\multicolumn{3}{|c|}{ Not Available }} \\
\hline 24 & & & \\
\hline
\end{tabular}


the inappropriate design or control strategy, defective parts, lack of maintenance, etc. Further in-depth investigations in these buildings are needed to find out the real reasons.

Table 9 shows the average values of the site EUIs, energy cost densities, and energy and energy cost savings by different building types, where the information for residential buildings is not shown, due to the limited energy information obtained from the building owners for that type of building. As shown in this table, college, commercial, and public buildings had higher site EUIs and energy cost densities compared to school or church buildings, mainly due to various operation schedules of different types of buildings. Unlike the other buildings, church buildings are not necessary to operate heavily during weekdays, and school buildings are not typically used very often during a summer break. Additionally, this table shows that positive energy and energy cost savings were achieved for commercial and college buildings, while school, church, and public buildings consumed more energy and had higher utility costs compared to the national median EPA results. The discussions above may indicate that the more often and heavier a GHP system is used, the more energy and energy cost savings would be achieved.

Table 8. Average value comparison of energy and energy cost savings.

\begin{tabular}{lcc}
\hline & Average & Range \\
\hline Site EUI - Actual GHP System $\left[\mathrm{kWh} / \mathrm{m}^{2} / \mathrm{yr}\right]$ & 178.1 & $96.9-274.7$ \\
Site EUI - EPA Similar Building $\left[\mathrm{kWh} / \mathrm{m}^{2} / \mathrm{yr}\right]$ & 202.4 & $97.9-371.6$ \\
Energy Cost Density - Actual GHP System $\left[\$ / \mathrm{m}^{2} / \mathrm{yr}\right]$ & 13.13 & $7.00-22.17$ \\
Energy Cost Density - EPA Similar Building $\left[\$ / \mathrm{m}^{2} / \mathrm{yr}\right]$ & 14.96 & $6.89-26.05$ \\
Energy Savings Compared to Similar Buildings $(\mathrm{EPA})$ & $7.2 \%$ & $-36 \%-43 \%$ \\
Energy Cost Savings Compared to Similar Buildings (EPA) & $6.1 \%$ & $-35 \%-43 \%$
\end{tabular}

Table 9. Average value comparison of energy and energy cost savings by building type.

\begin{tabular}{|c|c|c|c|c|c|}
\hline & College & School & Church & Commercial & Public \\
\hline $\begin{array}{l}\text { Site EUI - Actual GHP } \\
\text { System }\left[\mathrm{kWh} / \mathrm{m}^{2} / \mathrm{yr}\right]\end{array}$ & 201.4 & 156.0 & 131.0 & 185.6 & 220.0 \\
\hline $\begin{array}{l}\text { Site EUI - EPA Similar } \\
\text { Building }\left[\mathrm{kWh} / \mathrm{m}^{2} / \mathrm{yr}\right]\end{array}$ & 253.2 & 144.9 & 130.1 & 239.3 & 215.9 \\
\hline $\begin{array}{l}\text { Energy Cost Density - Actual } \\
\text { GHP System }\left[\$ / \mathrm{m}^{2} / \mathrm{yr}\right]\end{array}$ & 15.07 & 10.76 & 7.75 & 16.47 & 14.21 \\
\hline $\begin{array}{l}\text { Energy Cost Density - EPA } \\
\text { Similar Building }\left[\$ / \mathrm{m}^{2} / \mathrm{yr}\right]\end{array}$ & 18.19 & 10.12 & 7.75 & 22.17 & 12.81 \\
\hline $\begin{array}{l}\text { Energy Savings Compared } \\
\text { to Similar Buildings (EPA) }\end{array}$ & $15 \%$ & $-8 \%$ & $-1 \%$ & $25 \%$ & $-2 \%$ \\
\hline $\begin{array}{l}\text { Energy Cost Savings Compared } \\
\text { to Similar Buildings (EPA) }\end{array}$ & $12 \%$ & $-8 \%$ & $-1 \%$ & $27 \%$ & $-11 \%$ \\
\hline
\end{tabular}




\subsection{Building Cost Demonstration}

Table 10 shows the average costs of the investigated buildings, including capital building cost, total HVAC system cost, and annual repair and maintenance expenses per building floor areas.

Table 11 shows the comparison of the average HVAC/GHP system cost (including the exterior and interior HVAC system costs) among different investigations and studies over time. Figure 5 indicates the trend of the average system cost in terms of $\$ / \mathrm{m}^{2}$. As shown in this figure, the average system cost rises gradually among the investigations from 1995 to 2017, and it has been increased by $143 \%$ (from 97.63 to $237.45 \$ / \mathrm{m}^{2}$ ). This increase may indicate the loss of cost effectiveness to install and use a GHP system in a building, due to a longer payback period. This may eventually result in the loss of attraction of building owners/developers to GHP systems, who would rather use conventional HVAC systems that usually have low capital costs but consume more energy and fossil fuels, which will be against the original intention of the state or local governments about energy efficiency and environmental protection. Therefore, the financial support either from governments or utility companies, or both, would give a much needed shot in the arm to the popularity of GHP systems in North America by improving the cost effectiveness of using GHP systems, and thus encouraging the nationwide installation of GHP systems and making use of geothermal energy.

Table 10. Average building and HVAC costs.

\begin{tabular}{lcc}
\hline & Average & Range \\
\hline Capital building cost per floor areas $\left[\$ / \mathrm{m}^{2}\right]$ & 1804.05 & $676.84-4810.11$ \\
Total HVAC cost per floor areas $\left[\$ / \mathrm{m}^{2}\right]$ & 237.45 & $117.54-384.71$ \\
$\begin{array}{l}\text { HVAC system average annual repair and } \\
\text { maintenance cost per floor areas }\left[\$ / \mathrm{m}^{2}\right]\end{array}$ & 1.08 & $0.54-1.61$ \\
\hline
\end{tabular}

Table 11. Average HVAC cost comparison.

\begin{tabular}{ccc}
\hline & \multicolumn{2}{c}{ Total HVAC cost per floor areas $\left(\$ / \mathrm{m}^{2}\right)$} \\
\hline ASHRAE, $1995[30]$ & Average & 97.63 \\
& Range & $28.74-154.36$ \\
ASHRAE, $1998[31]$ & Average & 100.32 \\
Zimmerman, 2000 [39] & Range & $28.74-175.99$ \\
& Average & 140.79 \\
Kavanaugh et al., 2012 [35] & Range & $97.95-187.40$ \\
This Paper (2017) & Average & 223.35 \\
& Range & $143.59-280.94$ \\
& Average & 237.45 \\
\hline
\end{tabular}




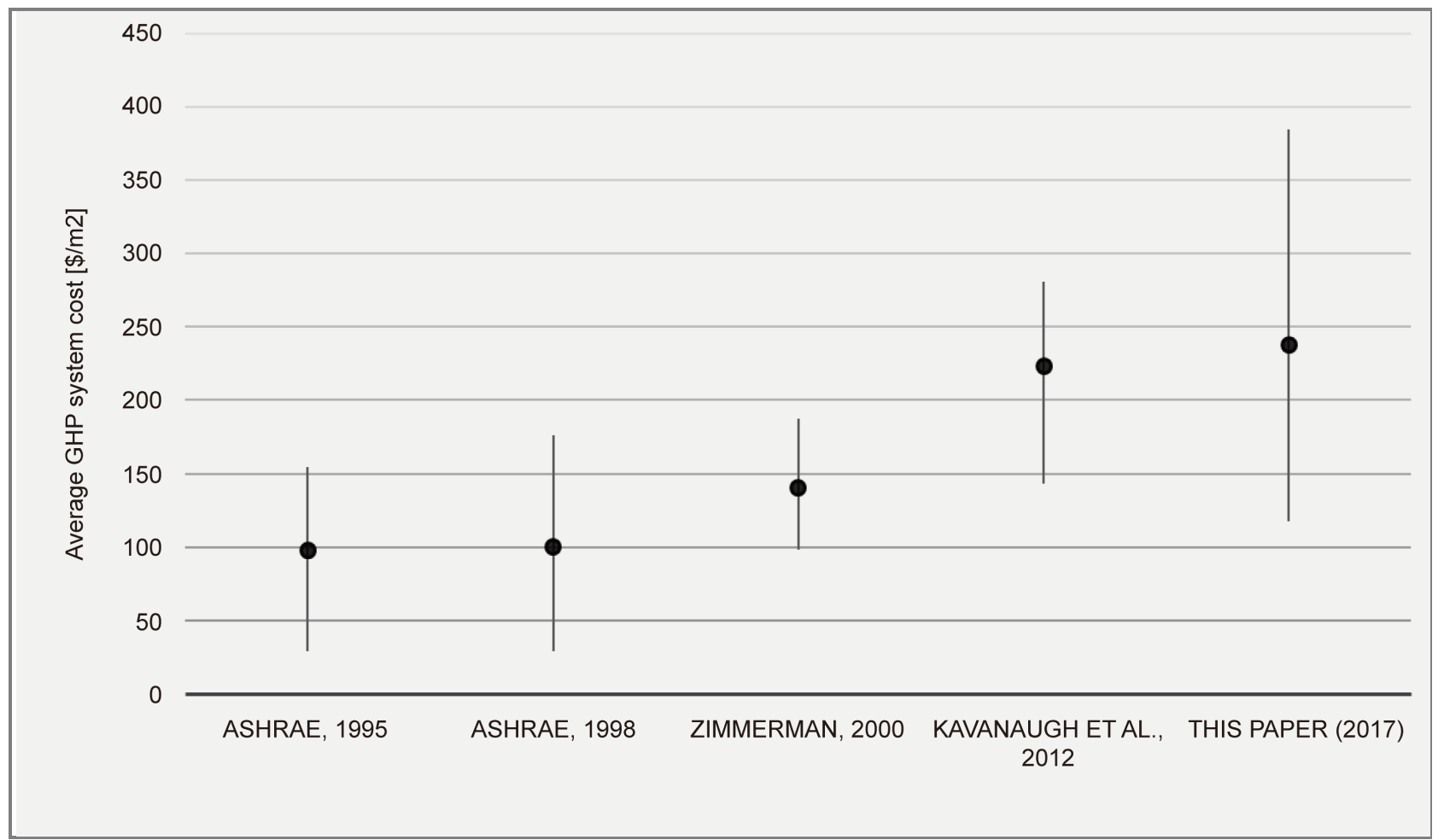

Figure 5. Trend of average HVAC/GHP system costs over time.

\subsection{Owner Satisfaction}

In the survey questionnaires, the respondents were asked to answer these three questions:

1) Are you satisfied with the current HVAC system in terms of noise, cost, and indoor comfort? Any complaints from building end users?

2) As you know, are there any operating difficulties of the geothermal heat pump system?

3) Would you like to suggest geothermal heat pump systems to others, like your friends?

Figures 6-8 show the survey results for these three questions. As shown in Figure $6,75 \%$ of the respondents who answered the first question are very satisfied with their GHP systems in terms of noise, cost, and indoor comfort. About $71 \%$ of the investigated GHP systems (according to the total respondents who answered the second question) have not had serious operating difficulties (Figure 7), and $85 \%$ of the respondents who answered the third question would suggest this type of system to other people (Figure 8).

Several key points or takeaways from this survey are summarized and listed below, which were provided by building owners/operators.

- High initial costs of GHP system and whether it is affordable for building owners.

- Warm ground issues for GHP systems due to the unbalanced heating and cooling loads and inappropriate underground loop design.

- Inappropriate thermostat control strategies may cause discomfort. 


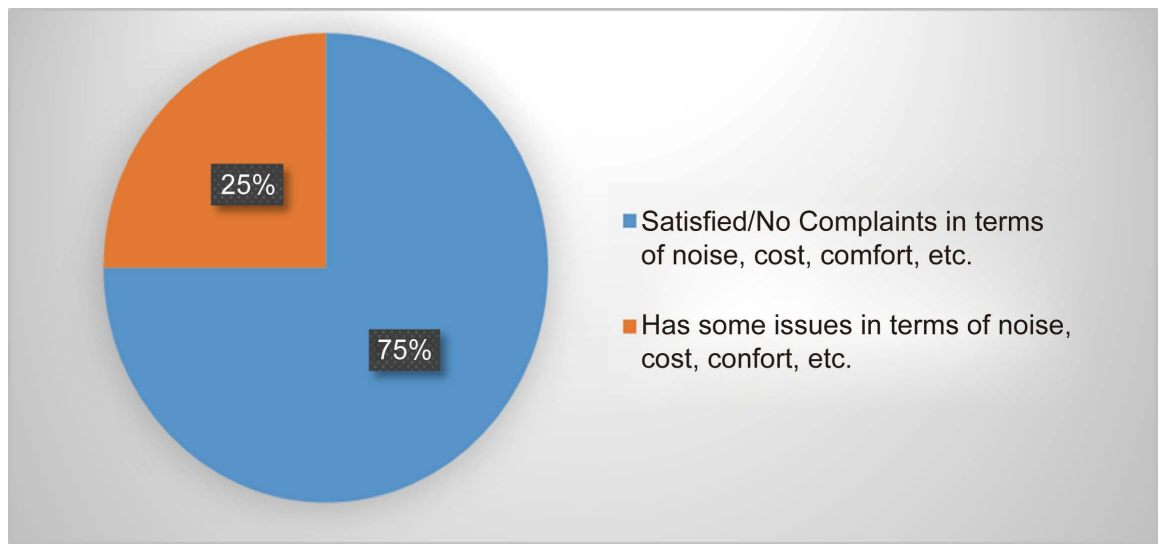

Figure 6. Survey result for noise, cost and comfort.

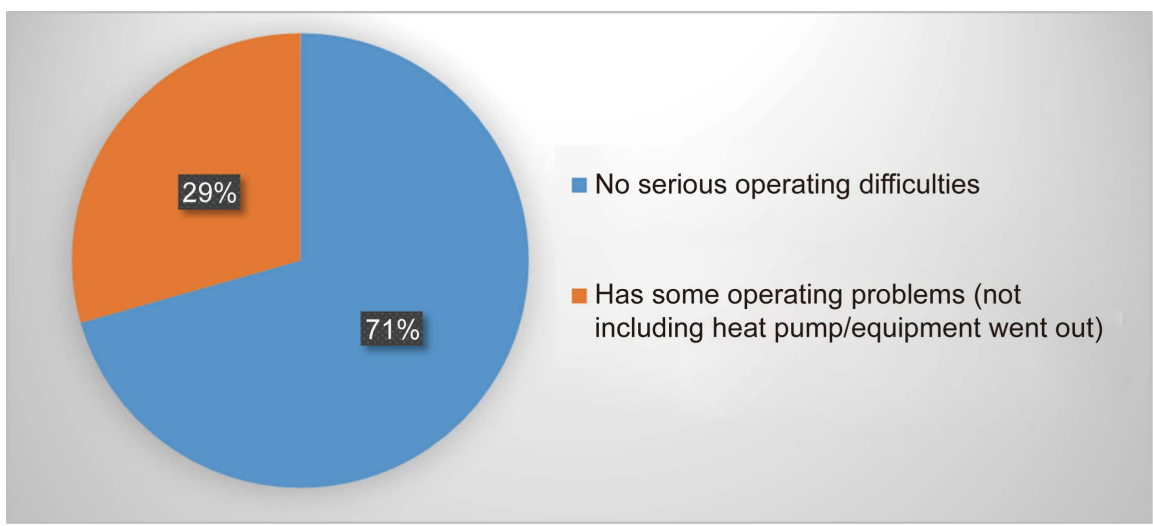

Figure 7. Survey result for operating difficulties.

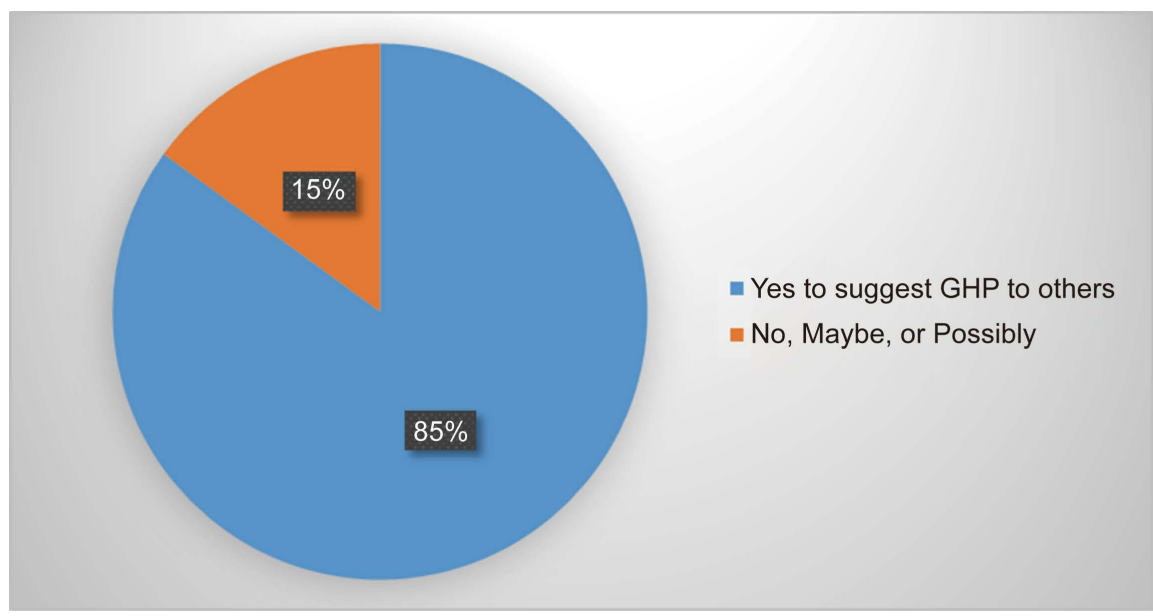

Figure 8. Survey result for suggesting GHP to others.

- Simultaneous heating and cooling may exist in a large open space that is served by two or more heat pump units with more than one thermostat.

- In a cold-climate region, heat pump units are sized based on heating loads due to a cold winter, which may cause the oversizing for cooling coils and overcooling.

- Heat pump replacement costs are expensive. 
- Slow response of the GHP system to the change of building cooling/heating loads.

- The difficulties for the geothermal system to initially start up during the first winter, due to the absence of a backup heating system and that the underground region had not absorbed enough building heat during the summer period.

- The antifreeze used in old heat pump systems might be corrosive, which may cause environmental issues.

- GHP systems are not appropriate for all the buildings in cold-climate regions. It depends on the application and scale of the project and what other heating systems are available. Geothermal energy can be a great choice in the right scenario.

- Incentives can help to reduce the high installation costs of GHP systems.

- Supplemental/backup heating for GHP systems seems necessary in coldclimate regions.

\section{Conclusions}

In this study, onsite surveys and investigations of 24 buildings were carried out. These investigated buildings located in the cold-climate regions of the US include 9 college buildings, 6 school buildings, 2 churches, 3 commercial buildings, 2 public buildings, and 2 residential buildings. The conclusions of this study are listed below.

- Currently, one of the biggest barriers to the wide application of GHP system in the investigated regions of the US is the high capital and/or replacement cost. Reduction of capital costs and improvement of cost effectiveness of installing and using this type of system are the keys. Financial support from local governments and/or utility companies would give a much needed shot in the arm to the popularity of GHP systems in the cold-climate regions of the US.

- The major reasons for installing geothermal systems include "lower cooling and heating bills", "energy efficiency", and "environmental concerns". Although some of the building owners expressed more concerns about energy and environment, instead of "money", these building owners are limited to non-profit organizations, such as colleges or schools. "Lower cooling and heating bills" is still the top concern for commercial building owners.

- For these 24 buildings, $75 \%$ of the building owners are very satisfied with their GHP systems in terms of noise, cost, and indoor comfort; about $71 \%$ of the investigated GHP systems have not had serious operating difficulties; and more than $85 \%$ of the respondents would suggest this type of system to other people. These survey results indicate the reliability and applicability of GHP systems in the cold-climate regions of the US as well as the potential for a broader statewide/nationwide application.

- Compared to the national median of energy use and energy cost of typical buildings of the same type nationwide, the overall performance of the actual 
GHP systems used in the cold-climate regions is slightly better, i.e. about $7.2 \%$ energy savings and $6.1 \%$ energy cost savings on average. The relatively low energy and energy cost savings compared to similar buildings nationwide may cause the loss of attraction of building owners/developers to GHP systems, who would rather use conventional HVAC systems that usually have low capital costs but consume more energy and fossil fuels. This will be against the original intention of the state or local governments about energy efficiency and environmental protection.

- Compared to other buildings, higher energy and energy cost savings were achieved by the college and commercial buildings investigated, which may indicate that the more often and heavier a GHP system is used, the more energy and energy cost savings would be achieved. Therefore, in cold-climate regions, a GHP system would be more suitable and attractive for use in college or commercial buildings than schools or churches.

- On average, the design water flow rate per $\mathrm{kW}$ (total cooling capacity), i.e. 3.7 $\mathrm{L} / \mathrm{min} / \mathrm{kW}$ with a range between 2.3 and 5.8 , for the ground loops of the investigated GHP systems is slightly more than the upper level of the typical values $(2.7-3.2 \mathrm{~L} / \mathrm{min} / \mathrm{kW})$. This may indicate the oversizing of water flow rate in ground loops, which may result in higher pump power and increased operational costs.

- In the cold-climate regions of the US, the issues regarding warm ground and high return water temperatures do exist. One of these investigated systems (Building 2 - a cooling-dominated building) had already encountered a serious operating issue, i.e. high return water temperatures (warm ground) and low cooling capacities, due to the unbalanced cooling and heating loads, a shorter borehole separation distance, the low thermal conductivity of the grout material, and/or an insufficient underground heat exchanger length.

- In these northern regions of the US, on average, the depth of GHP boreholes is typically about 61 meters below the ground surface, due to the local geologic formations and the relatively high water table. Additionally, test wells before the installation of a GHP system are suggested, which are not only able to test the thermal performance of the underground region, but also to ensure how deep the geothermal loops can go and the depth of the water table in that region.

- Supplemental/backup heating for GHP systems is suggested and sometimes necessary, especially for the initial startup during the first and/or unexpectedly cold winters in cold-climate regions, but unfortunately, most of the investigated GHP systems used in the cold-climate regions are not equipped with any supplemental heating devices (regardless of unit heaters used in heating-only spaces).

In this study, 24 buildings have been investigated through onsite surveys and questionnaires, but not all the necessary information was collected or provided by building owners, which limited the number of buildings for in-depth analysis. Therefore, future work is needed in these unexplored research areas. Addition- 
ally, more buildings, especially residential buildings or single houses, could be studied to enhance the statewide/nationwide influence and engagement of this study.

\section{Acknowledgements}

The authors would like to acknowledge the support of the North Dakota Department of Commerce, Office of Renewable Energy \& Energy Efficiency, through the State Energy Program with the grant number: DE-EE0006216.

\section{References}

[1] Kelso, J.D. (2010) Buildings Energy Data Book. U.S. Department of Energy (DOE), Washington DC. http://web.archive.org/web/20130214024505/http://buildingsdatabook.eren.doe.gov /ChapterIntro1.aspx

[2] David, A., Mathiesen, B.V., Averfalk, H., Werner, S. and Lund, H. (2017) Heat Roadmap Europe: Large-Scale Electric Heat Pumps in District Heating Systems. Energies, 10, 578. https://doi.org/10.3390/en10040578

[3] Arat, H. and Arslan, O. (2017) Exergoeconomic Analysis of District Heating System Boosted by the Geothermal Heat Pump. Energy, 119, 1159-1170. https://doi.org/10.1016/j.energy.2016.11.073

[4] Liu, Z., Xu, W., Qian, C., Chen, X. and Jin, G. (2015) Investigation on the Feasibility and Performance of Ground Source Heat Pump (GSHP) in Three Cities in Cold Climate Zone, China. Renewable Energy, 84, 89-96. https://doi.org/10.1016/j.renene.2015.06.019

[5] Self, S.J., Reddy, B.V. and Rosen, M.A. (2013) Geothermal Heat Pump Systems: Status Review and Comparison with Other Heating Options. Applied Energy, 101, 341-348. https://doi.org/10.1016/j.apenergy.2012.01.048

[6] Lohani, S.P. and Schmidt, D. (2010) Comparison of Energy and Exergy Analysis of Fossil Plant, Ground and Air Source Heat Pump Building Heating System. Renewable Energy, 35, 1275-1282. https://doi.org/10.1016/j.renene.2009.10.002

[7] Urchueguía, J.F., Zacarés, M., Corberán, J.M., Montero, A., Martos, J. and Witte, H. (2008) Comparison between the Energy Performance of a Ground Coupled Water to Water Heat Pump System and an Air to Water Heat Pump System for Feating and Cooling in Typical Conditions of the European Mediterranean Coast. Energy Conversion and Management, 49, 2917-2923.

https://doi.org/10.1016/j.enconman.2008.03.001

[8] Healy, P.F. and Ugursal, V.I. (1997) Performance and Economic Feasibility of Ground Source Heat Pumps in Cold Climate. International Journal of Energy Research, 21, 857-870. https://doi.org/10.1002/(SICI)1099-114X(199708)21:10<857::AID-ER279>3.0.CO;2-1

[9] Hepbasli, A. (2005) Thermodynamic Analysis of a Ground-Source Heat Pump System for District Heating. International Journal of Energy Research, 29, 671-687. https://doi.org/10.1002/er.1099

[10] Bakirci, K. (2010) Evaluation of the Performance of a Ground-Source Heat-Pump System with Series GHE (Ground Heat Exchanger) in the Cold Climate Region. Energy, 35, 3088-3096. https://doi.org/10.1016/j.energy.2010.03.054

[11] Ozyurt, O. and Ekinci, D.A. (2011) Experimental Study of Vertical Ground-Source Heat Pump Performance Evaluation for Cold Climate in Turkey. Applied Energy, 
88, 1257-1265. https://doi.org/10.1016/j.apenergy.2010.10.046

[12] Flaga-Maryanczyk, A., Schnotale, J., Radon, J. and Was, K. (2014) Experimental Measurements and CFD Simulation of a Ground Source Heat Exchanger Operating at a Cold Climate for a Passive House Ventilation System. Energy and Buildings, 68, 562-570. https://doi.org/10.1016/j.enbuild.2013.09.008

[13] Ozgener, O. and Hepbasli, A. (2005) Performance Analysis of a Solar-Assisted Ground-Source Heat Pump System for Greenhouse Heating: An Experimental Study. Building and Environment, 40, 1040-1050. https://doi.org/10.1016/j.buildenv.2004.08.030

[14] Chiasson, A. and Center, P.G.H. (2006) Greenhouse Heating with Geothermal Heat Pump Systems. ASABE Annual International Meeting Portland, 9-12.

[15] Tong, Y., Kozai, T., Nishioka, N. and Ohyama, K. (2010) Greenhouse Heating Using Heat Pumps with a High Coefficient of Performance (COP). Biosystems Engineering, 106, 405-411. https://doi.org/10.1016/j.biosystemseng.2010.05.003

[16] Chargui, R., Sammouda, H. and Farhat, A. (2012) Geothermal Heat Pump in Heating Mode: Modeling and Simulation on TRNSYS. International Journal of Refrigeration, 35, 1824-1832. https://doi.org/10.1016/j.ijrefrig.2012.06.002

[17] Chai, L., Ma, C. and Ni, J.Q. (2012) Performance Evaluation of Ground Source Heat Pump System for Greenhouse Heating in Northern China. Biosystems Engineering, 111, 107-117. https://doi.org/10.1016/j.biosystemseng.2011.11.002

[18] Benli, H. (2013) A Performance Comparison between a Horizontal Source and a Vertical Source Heat Pump Systems for a Greenhouse Heating in the Mild Climate Elaziğ, Turkey. Applied Thermal Engineering, 50, 197-206. https://doi.org/10.1016/j.applthermaleng.2012.06.005

[19] Esen, M. and Yuksel, T. (2013) Experimental Evaluation of Using Various Renewable Energy Sources for Heating a Greenhouse. Energy and Buildings, 65, 340-351. https://doi.org/10.1016/j.enbuild.2013.06.018

[20] Russo, G., Anifantis, A.S., Verdiani, G. and Mugnozza, G.S. (2014) Environmental Analysis of Geothermal Heat Pump and LPG Greenhouse Heating Systems. Biosystems Engineering, 127, 11-23. https://doi.org/10.1016/j.biosystemseng.2014.08.002

[21] Fang, H., Yang, Q.C. and Sun, J. (2008) Application of Ground-Source Heat Pump and Floor Heating System to Greenhouse Heating in Winter. Transactions of the Chinese Society of Agricultural Engineering, 24, 145-149.

[22] Chiasson, A.D., Spitler, J.D., Rees, S.J. and Smith, M.D. (2000) A Model for Simulating the Performance of a Pavement Heating System as a Supplemental Heat Rejecter with Closed-Loop Ground-Source Heat Pump Systems. Journal of Solar Energy Engineering, 122, 183-191. https://doi.org/10.1115/1.1330725

[23] Zwarycz, K. (2002) Snow Melting and Heating Systems Based on Geothermal Heat Pumps at Goleniow Airport, Poland. The United Nations University Geothermal Training Programme Reports, 21, 431-464.

[24] Wang, H., Zhao, J. and Chen, Z. (2008) Experimental Investigation of Ice and Snow Melting Process on Pavement Utilizing Geothermal Tail Water. Energy Conversion and Management, 49, 1538-1546. https://doi.org/10.1016/j.enconman.2007.12.008

[25] Balbay, A. and Esen, M. (2010) Experimental Investigation of Using Ground Source Heat Pump System for Snow Melting on Pavements and Bridge Decks. Scientific Research and Essays, 5, 3955-3966.

[26] He, Q. and Shi, L. (2016) Design and Research of High-Speed Turnout Snow Melting System Based on Ground Source Heat Pump. Journal of Residuals Science \& Technology, 13. 
[27] Ryan, W. (2011) Carbon Emission Comparison between Residential Heating and Cooling Options. Mechanical and Industrial Engineering Department, University of Illinois, Chicago.

[28] American Society of Heating Refrigerating and Airconditioning Engineer (2007) ANSI/ASHRAE Standard 90.1-2007, Energy Standard for Buildings except LowRise Residential Buildings. American Society of Heating Refrigerating and Airconditioning Engineer, Atlanta

[29] EPA's Target Finder Calculator. http://www.energystar.gov/buildings/service-providers/design/step-step-process/ev aluate-target/epa $\% \mathrm{E} 2 \% 80 \% 99$ s-target-finder-calculator

[30] American Society of Heating Refrigerating and Airconditioning Engineer (1995) Operating Experiences with Commercial Ground-Source Heat Pump Systems, Final Report TRP-863. American Society of Heating Refrigerating and Airconditioning Engineer, Atlanta.

[31] American Society of Heating Refrigerating and Airconditioning Engineer (1998) Operating Experiences with Commercial Ground-Source Heat Pump Systems. American Society of Heating Refrigerating and Airconditioning Engineer., Atlanta.

[32] Kavanaugh, S. and Kavanaugh, J. (2012) Long-Term Commercial GSHP Performance: Part 1: Project Overview and Loop Circuit Types. ASHRAE Journal, 54, 48.

[33] Kavanaugh, S. and Kavanaugh, J. (2012) Long-Term Commercial GSHP Performance: Part 2: Ground Loops, Pumps, Ventilation Air and Controls. ASHRAE Journal, 54, 26.

[34] Kavanaugh, S. and Kavanaugh, J. (2012) Long-Term Commercial GSHP Performance: Part 3: Loop Temperatures. ASHRAE Journal, 54, 28-39.

[35] Kavanaugh, S., Green, M. and Mescher, K. (2012) Long Term Commercial GSHP Performance: Part 4: Installation Costs. ASHRAE Journal, 54, 26-34.

[36] Kavanaugh, S. and Kavanaugh, J. (2012) Long-Term Commercial GSHP Performance: Part 5: Comfort and Satisfaction. ASHRAE Journal, 54, 32-37.

[37] Kavanaugh, S. and Dinse, D. (2013) Long-Term Commercial GSHP Performance: Part 6: Maintenance and Controls. ASHRAE Journal, 55, 24.

[38] Kavanaugh, S. and Meline, L. (2013) Long-Term Commercial GSHP Performance: Part 7: Achieving Quality. ASHRAE Journal, 55, 26-31.

[39] Zimmerman, D.R. (2000) Documentation of Operation, Maintenance \& Construction Cost of Geothermal Heat Pump Systems in Schools. Final Report. EPP3128/C1476. Electric Power Research Institute, Palo Alto.

[40] Manz, L. (2011) Another First for North Dakota. Geothermal Energy Update. Geo News, 5-6.

[41] Kavanaugh, S. and Rafferty, K. (2014) Geothermal Heating and Cooling Design of Ground-Source Heat Pump Systems. American Society of Heating Refrigerating and Airconditioning Engineer, Atlanta.

[42] American Society of Heating Refrigerating and Airconditioning Engineer (2015) Chapter 34, Geothermal Energy. American Society of Heating Refrigerating and Airconditioning Engineer, Atlanta.

[43] American Society of Heating Refrigerating and Airconditioning Engineer (2004) ANSI/ASHRAE Standard 90.1-2004, Energy Standard for Buildings except LowRise Residential Buildings. American Society of Heating Refrigerating and Airconditioning Engineer, Atlanta. 
Submit or recommend next manuscript to SCIRP and we will provide best service for you:

Accepting pre-submission inquiries through Email, Facebook, LinkedIn, Twitter, etc. A wide selection of journals (inclusive of 9 subjects, more than 200 journals)

Providing 24-hour high-quality service

User-friendly online submission system

Fair and swift peer-review system

Efficient typesetting and proofreading procedure

Display of the result of downloads and visits, as well as the number of cited articles Maximum dissemination of your research work

Submit your manuscript at: http://papersubmission.scirp.org/

Or contact eng@scirp.org 